\title{
Д.А. Хитров
}

\section{ВОЛОГОДСКИЙ УЕЗД \\ И АДМИНИСТРАТИВНАЯ РЕФОРМА I775-I783 гг.}

Аннотация В статье на основе картографических материалов и хозяйственных описаний реконструируются границы Вологодского уезда в первой половине - середине XVIII в. и рассматривается вопрос о характеpe тех изменений, которые произошли в административном устройстве этих территорий при открытии Вологодского наместничества в 1780 г. Показано, что Вологодский уезд составил основу обширной западной части нового наместничества, и основная часть его территории вошла в состав четырех уездов Вологодской области Вологодского наместничества - Вельского, Кадниковского, Вологодского и Грязовецкого. Небольшие участки были также переданы Пошехонскому, Тотемскому и Череповецкому уездам, а в состав Грязовецкого уезда вошел ряд территорий Пошехонского, а также приграничные поселения Ярославского, Галичского и Любимского уездов.

Ключевые слова: губернская реформа 1775-1783 гг, Вологодский уезд, Вологодское наместничество, историческая картография.

Summary On the basis of cartographic materials and economic descriptions, the article reconstructs the boundaries of the Vologda Uyezd in the first half — middle of the XVIII century and considers the nature of the changes that occurred in the administrative structure of these territories when the Vologda viceroyalty was opened in 1780. It is shown that the Vologda uyezd formed the basis of the vast western part of the new viceroyalty, and the main part of its territory became part of the four uyezds of the Vologda region of the Vologda viceroyalty - Velsky, Kadnikovsky, Vologda and Gryazovets. Small areas were also transferred to Poshekhonsky, Totemsky and Cherepovets counties, and Gryazovets County included a number of territories of Poshekhonsky, as well as border settlements of Yaroslavl, Galichsky and Lyubimsky counties. Keywords: Provincial Reform of 1775-1783, Vologda uyezd, Vologda viceroyalty, historical cartography.

1 Исследование выполнено при финансовой поддержке РФФИ, проект № 19-09-00462 (а). 
Работы Е.Н. Швейковской показывают, какие широкие возможности открывают перед исследователями демографических и социальных процессов в северорусской деревне XVII-XVIII вв. разного рода материалы государственного учета земель и налогоплательщиков этого времени. В ее исследованиях на основании этих внешне суховатых статистических данных перед нами предстает сложный, пронизанный внутренними связями мир - эти связи, увиденные глазами историка, соединяют не только современников, но и людей разных поколений и даже разных эпох. Длительной устойчивости социального устройства северного «мира» соответствовала и стабильность традиционного административно-территориального деления, которое, оформившись в период присоединения северорусских земель к Московскому государству, без существенных изменений просуществовало вплоть до екатерининской реформы 1775-1783 гг.

Знание того, какие территории относились в XVI-XVIII вв. к той или иной административной единице, важно со многих точек зрения. Во-первых, без этого трудно представить себе происходившие процессы в территориальном разрезе, а методы исторической картографии и пространственного анализа приобретают все большее значение в современных исследованиях. Во-вторых, агрегированные статистические данные, от писцовых итогов до уездных табелей Генерального межевания, относятся, естественно, к существовавшему на момент их создания административному делению, и знание этого деления необходимо для их корректного анализа. Кроме того, необходимо иметь в виду и практическое значение этого вопроса для исследователей, занимающихся архивными поисками в рамках разного рода микроисторических работ - краеведческих, биографических или генеалогических. Комплексы массовых источников этой эпохи, таких как ревизии, материалы Генерального межевания, губернаторские отчеты и многие другие, структурированы именно в соответствии с существовавшим на момент их создания административным делением, и одна из главных трудностей, с которыми сталкивается работающий с ними исследователь, связана именно с неизученностью истории этого деления.

Реконструкции административного деления того или иного периода обычно опираются на карты соответствующей эпохи. Правда, картографические съемки XVIII-XIX вв., не говоря о более ранних, нередко далеки от современного стандарта — прежде всего из-за отсутствия в распоряжении геодезистов того времени аэро- или космических снимков, несовершенства методов определения координат и неточности самих координатных систем. Тем не менее, если сама съемка, лежащая в основе карты, была осуществлена качественно и включала достаточно большое количество измерений, 
современные средства работы с историческими картами позволяют выправить большую часть подобных искажений. Указав некоторое количество контрольных точек (их число прямо зависит от качества исходной карты - скажем, для уездных карт начала XX в. чаще всего достаточно 10-15, а карта конца XVIII-го, как правило, требует нескольких сотен) и подобрав подходящий алгоритм трансформации, мы можем с достаточно высокой точностью совместить историческую карту с современной к геооснове, осуществить так называемую привязку: программа, использовав данные о положении заданных точек на образе (скане) карты и их положение на современной координатной сетке, «выправит» искажения. С привязанной карты можно перенести на современную основу и отмеченные на ней объекты, в частности границы.

Однако для реконструкции административных границ XVI - первой половины XVIII вв. такой подход мало применим. Причина в том, что, как известно, губернская реформа 1775-1783 гг. была сопряжена с весьма решительным пересмотром границ губерний и уездов, и использовать «пореформенные» карты при рассмотрении «дореформенного деления невозможно. Между тем карты, отражающие «дореформенное» деление, есть не по всем уездам, а там, где они имеются, их использование сопряжено с серьезными затруднениями.

До второй половины XVIII в. уровень развития русской крупномасштабной картографии был, как известно, не слишком высок². Большие работы были предприняты под эгидой Академии наук в 1720-1750-х гг., но, хотя замысел Петра I предполагал использование самых современных на тот момент методик картографической съемки, и в результате было составлено значительное число уездных карт, так называемых карт петровских геодезистов. Эти карты мало пригодны для привязки, поскольку в их основе лежало сравнительно небольшое число полевых измерений ${ }^{3}$. Геодезисты, работая в определенном уезде, пересекали его территорию одним или двум «инструментальными ходами», а все остальные объекты, прежде всего реки и поселения, восстанавливались на основе составлявшихся на основе ревизских материалов списков населенных мест, а также рассказов местных жителей. Близкой методикой составления отличались и карты, созданные Межевым департаментом Сената по ряду территорий в 1760-х гг.,

2 См.: Фель С.Е. Картография России XVIII в. М., 1960; Постников А.В. Развитие крупномасштабной картографии в России. М., 1989.

3 Багров Л. История русской картографии. М., 2005; Гольденберг Л.А. Первый академический атлас России и картографические работы Географического департамента Академии наук // Очерки истории географической науки в СССР. М., 1976. 
до начала массовых работ Генерального межевания. Понятно, что точность расположения на карте таких объектов была крайне невысока: направление рек часто показывалось неверно, а локализация поселений и вовсе была приблизительной. В сущности, карты этой эпохи представляют собой довольно приблизительные схемы систем расселения: авторы стремились отобразить существовавшие населенные пункты и примерно показать их взаимное расположение.

Однако хуже всего на этих картах отображались границы: в сущности, нанеся на лист поселения, картограф просто обводил их общей, примерной округлой линией. В результате возникали ситуации, когда территории, на которых, в силу причудливости очертаний границ, существовали поселения двух разных уездов, изображались на картах двух смежных уездов дважды: на каждую из них наносились только относившиеся к этому уезду села и деревни. Понятно, что, даже если такую карту удается более или менее приемлемым образом «привязать», смысла в том, чтобы анализировать расположение показанной на ней границы, немного: сама эта линия не была результатом полевой съемки и не отражает существовавшую «на местности» реальность.

В силу этого исследователи, занимающиеся историей административно-территориального деления XVI-XVIII вв., чаще всего идут по другому пути - составляют списки поселений на основе того или иного налогового описания, а затем локализуют их, используя более поздние карты (иногда даже современные $)^{4}$. У такого подхода, имеющего длительную традицию в историографии, есть очевидные плюсы, но и не менее серьезные ограничения.

Во-первых, список поселений, извлеченный из писцовой или переписной книги, почти никогда не удается локализовать полностью - всегда обнаруживается какое-то количество поселений, которые либо исчезли, либо поменяли название к тому времени, как были составлены первые карты, которые могли бы зафиксировать локализацию соответствующего топонима (особенно это существенно для описаний XVII — начала XVIII в., поскольку, как отметил еще М.В. Витов, проведение первой ревизии было сопряжено с решительным отказом от старой традиции преемственных друг по отношению к другу описаний XVII в., и в силу этого с существенным

${ }^{4}$ Подробно о методике такой работы см.: Водарский Я.Е. Население России в конце XVII - начале XVIII века: Численность, сословно-классовый состав, размещение. М., 1977. Приложение 11. Схемы уездов России конца XVII - начала XVIII в.; Кабузан B.M. Обзор историко-географических источников по административно-территориальному делению России в 1720-1770 гг. // Историческая география России XVIII в. М., 1981. С. 45-56. 
обновлением топонимики) $)^{5}$. Следовательно, исследователь всегда сталкивается с опасностью «не увидеть» какую-то часть уезда, стана или волости, расположенную на некотором отдалении от остальных; тяжелее всего в этом случае, конечно, найти анклавы или просто дальние, расположенные в окружении территорий соседнего уезда поселения.

Во-вторых, в подавляющем большинстве случаев такая реконструкция охватывает только один уезд. Это означает, что его границу исследователи обозначают примерно так же, как это делали геодезисты XVIII века - совокупность локализованных поселений обводится приблизительным общим контуром. Это отчасти оправданно, когда такая граница проходит по обширным незаселенным пространствам; но если речь идет о более или менее плотно заселенной территории, подобная реконструкция может ввести читателя в заблуждение, отнеся к исследуемому уезду земли и поселения, принадлежавшие на самом деле к соседнему.

Как представляется, этих ошибок позволяет избежать следование двум важным принципам при создании подобных реконструкций. Во-первых, при нанесении на карту границы следует использовать данные о положении крайних поселений обоих граничащих уездов. Часто это проще всего сделать при помощи карт первой половины XVIII в. Во-вторых, границу следует реконструировать с учетом данных более позднего времени. Как известно, при проведении реформы 1775-1783 гг. старая система деления не была полностью ликвидирована, стерта и создана заново: реформа осуществлялась путем передачи определенных участков от одних центров к другим. Картина этой «пересборки» административных единиц зачастую довольно сложна и мозаична, но значительная часть границ сохраняется и после реформы.

Между тем с картами «пореформенного» административного деления дело обстоит значительно лучше, чем с «дореформенными», что связано с началом в 1765 г. работ Генерального межевания. Для подавляющей части территорий, исключая только Московскую провинцию Московской губернии, межевание вышло на стадию составления уездных и губернских планов и атласов уже после открытия новых наместничеств, и эти планы и атласы отражают уже новое деление. Хотя в литературе существует мнение, что межевая картография в техническом отношении уступала работам более раннего времени (прежде всего из-за отсутствия требования определения координат), практика работы с этими картами показывает, что их привязка, хотя

5 Витов М.B. Приемы составления карт поселений XV-XVII вв. по данным писцовых и переписных книг (на примере Шунгского погоста Обонежской пятины) // Сборник Института этнографии АН СССР. М., 1958. Вып. 29. С. 30-37. 
и требует большого числа контрольных точек, позволяет достаточно точно позиционировать многочисленные объекты, расположенные на этих картах.

Отсутствие точно определенных координат (хотя, следует сказать, точность их определения в XVIII в. так или иначе была довольно относительной) вполне компенсировалось огромным количеством полевых измерений, причем эти измерения касались в первую очередь именно границ отдельных земельных дач. Распространенное мнение, что при сведении первичных картографических материалов, планов дач, в генеральные уездные планы и, далее, в карты наместничеств, допускались искажения, исключающие успешную привязку последних, также не подтверждается практикой. Такие искажения присутствуют, однако они весьма успешно корректируются алгоритмами привязки - измерения, лежащие в основе планов дач, учитывались при их сведении в единое полотно и выступали в качестве своеобразного «жесткого каркаса» сводной карты. Правда, и на межевых картах административные границы, нередко проходившие (особенно на Севере) по удаленным лесам и заболоченным водоразделам, измерялись и, соответственно, отображались не вполне точно - но в любом случае это были результаты полевых измерений, которые отражали (хотя, возможно, и не всегда идеально) существовавшую на местности реальность.

Вологодский уезд, занимающий одно из центральных мест в творчестве Е.Н. Швейковской, дает интересную возможность проверить действенность этого подхода. С одной стороны, по нему нет «дореформенных» карт XVIII в. (точнее, имеется обобщенная карта Вологодской провинции, на которой поселения нанесены выборочно, а граница показана очень приблизительно $)^{6}$. С другой стороны, он давно привлекает внимание исследователей, имеется целый ряд работ, посвященных истории его формирования и развития ${ }^{7}$, и, в частности, Я.Е. Водарским еще в 1970-х гг. был опубликован перечень поселений уезда, учтенных в переписных книгах 1678 г, а А.Л. Грязнов на основе этих данных составил его достаточно детальную карту ${ }^{8}$ Границы на ней, однако, показаны с той приблизительностью,

6 ОР БАН. Картографическое собрание Географического департамента АН. Оп. 1. Ед. хр. 556 (Ландкарта, сочиненная Вологодской провинции Вологодского и Тотемского уездов... 1736 года).

7 Грязнов А.Л., Черкасова М.С. О формировании межуездных границ на Русском Севере в XV-XVI вв.: Белоозеро-Вологда-Устюг // Северная Русь и проблемы формирования Древнерусского государства: Сборник материалов международной научной конференции. Вологда-Кириллов-Белозерск 6-8 июня 2012 г. Вологда, 2012. С. 178-192; Черкасова М.С. Северная Русь: История сурового края XIII-XVII вв. М., 2017.

${ }^{8}$ Водарский Я.Е. Вологодский уезд в XVII в. (К истории сельских поселений) // Аграрная история Европейского Севера СССР. Вологда, 1970. С. 253-366; Грязнов А.Л. Карта «Вологодский уезд в XVII в.» // Мой родной Вологодский район. Вологда, 2009. С. 96-97. 
которая, как мы говорили выше, неизбежна при такой методике реконструкции. Посмотрим, можно ли уточнить эти данные.

Как известно, дореформенный Вологодский уезд охватывал обширную территорию, составившую позже западную часть Вологодского наместничества, и граничил со следующими уездами (начиная с севера и двигаясь по часовой стрелке): Важским, небольшим участком Устюжского, Тотемским, Галичским и Любимским, небольшим участком Ярославского, Пошехонским, Белозерским, Чарондским, Каргопольским.

Как уже говорилось, подробной, отражающей всю сеть поселений «дореформенной» карты уезда в нашем распоряжении нет, хотя, она, видимо, была составлена (В.М. Кабузан выражал надежду, что такая карта обнаружится в собраниях Ж.-Н. Делиля в Париже или в Венсене, но ее, видимо, нет и там) ${ }^{9}$. Зато большие участки его границ видны на картах многих смежных территорий. Прежде всего, это подробная карта другого уезда Вологодской провинции, Тотемского, датируемая 1730-ми гг. ${ }^{10}$ Затем, это две большие карты значительных территорий Архангелогородской губернии, составленные в Межевом департаменте Сената в 1760-х гг. На одной из них, изображающей Среднее Подвинье с прилегающими землями, видна северо-восточная часть уезда, граничащая с Каргопольским, Важским, Устюжским и Тотемским уездами ${ }^{11}$, а на другой, охватывающей Костромское Заволжье, видны границы с Галичским уездом, Любимской осадой Костромского и участок границы с Ярославским ${ }^{12}$. Несколько более обобщенная карта тех же мест имеется в составе рукописного Лесного атласа 1782 г. $^{13}$ Западные границы - с Белозерским, Чарондским и Каргопольским уездами - видны на печатных картах И.К. Кирилова ${ }^{14}$.

9 Постников А.В. Новые данные о российских картографических материалах XVIII начала ХІХ вв. во Франции // Вопросы истории естествознания и техники. 2005. № 3; Голубинский А.А. Специфика работы представителей семьи Делиль над текстовыми материалами и черновой картографической информацией // Делили в России: сборник статей. СПб., 2019. C. 117-120.

${ }^{10}$ ОР БАН. Картографическое собрание Географического департамента АН. Оп. 1. Ед. хр. 533. Ландкарта Архангелогороцкой губернии Вологоцкой провинцыи Тотемскаго уезду... 1733 г.

${ }^{11}$ РГВИА. Ф. 846. Оп. 16. Ед. хр. 21224. Карта западной половине Архангелогородской губернии, в которой замыкается Устюжской, Двинской, Важеской, Кевролской, часть Тотемскаго, Вологодскаго и Каргополскаго уездов. Сочинена на 1765 году.

${ }^{12}$ РГВИА. Ф. ВУА. 846. Оп. 16. Ед. хр. 21226. Карта, представляющая южную часть Архангелогородской губернии с прилегающими к оной уездами по реку Волгу. Сочинена 1769 года.

${ }^{13}$ ОР РНБ. Эрм. 610. Карта 44. Карта Нижегородской губернии, содержащая Галицкую провинцию... 1751 г.

${ }^{14}$ Атлас Всероссийской империи. Собрание карт И.К. Кирилова. СПб., 1722-1737. Белозерской уезд и провинция. 1731; Ландкарта Каргопольского уезду. 1730. 
Таким образом, совсем отсутствует на картах XVIII в. только одна из границ Вологодского уезда - пошехонская.

Попробуем оценить, в какой степени использование карт первой половины XVIII в. и соотнесение границ, существовавших до реформ 1775 1783 гг., с пореформенными позволяют уточнить положение границ «старого» уезда, и для этого последовательно «пройдем» вдоль уездной границы, двигаясь по часовой стрелке.

Начнем с западной границы уезда. Здесь он граничит с Белозерским уездом, а далее к северу — с Чарондским и Каргопольским.

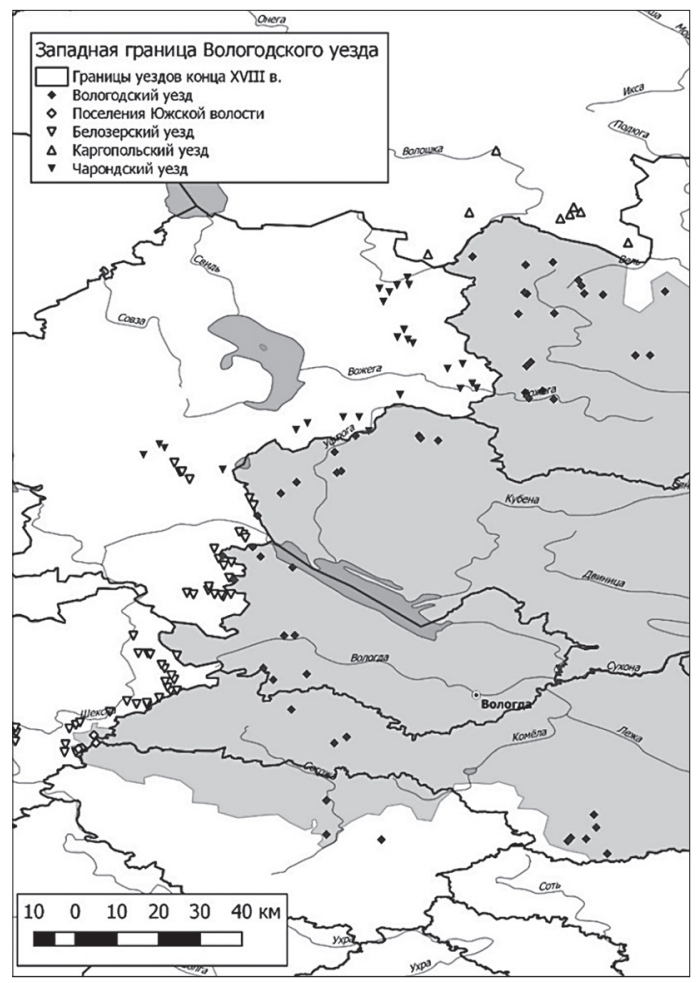

Карта 1. Западная граница Вологодского уезда

Как уже говорилось, все эти уезды отражены на печатных картах И.К. Кирилова; расположение поселений Вологодского уезда частично реконструируется на основании карты Вологодской провинции (правда, юго-западный угол этой карты практически не заполнен), а также отражено на карте А.Л. Грязнова. Поселения, отмеченные на картах И.К. Кирилова, прекрасно 
локализуются; значительная часть топонимики сохраняется даже на современных картах, а в тех случаях, когда она почему-либо утрачена (например, в связи с затоплением многих территорий по течению Шексны) - используются карты XVIII и XIX вв., прежде всего 10-верстная карта Стрельбицкого, а также карты Вологодского наместничества и Ярославской губернии из коллекции РГИА ${ }^{15}$.

Наложение границ уездов конца XVIII в. на эту картину показывает, что практически на всем протяжении западная граница дореформенного Вологодского уезда совпадает с границей пореформенного Вологодского наместничества (Грязовецкого, Вологодского, Кадниковского и, частично, Вельского уездов). Севернее Судьбицкого погоста (38.401; 59.152) вплоть до окрестностей каргопольского Валдиевского погоста и деревни Иванкинская (40.514; 60.268) более 100 поселений, показанных в качестве пограничных на картах Кирилова, плотно примыкают к этой линии с запада, и ни одно не локализуется восточнее ее; равным образом, карта А.Л. Грязнова не показывает вологодских владений западнее.

Следует отметить, что территория уезда простиралась на север несколько дальше, чем предполагал Я.Е. Водарский. Как на его схемах, так и на основанной на его материалах карте Грязнова к вологодским землям (Давыдовской волости) принадлежит только бассейн верхней Кубены. Между тем к ним следует, видимо, отнести и обширный водораздел Кубены и Волошки - на карте Вологодской провинции здесь отмечены деревня Зеленая, соотносимая с деревней Дальняя Зеленая (39.868; 61.005), село Спасское на оз. Глубоком, которое, видимо, следует соотнести с Глубоковским погостом и селом Фатуново (40.096; 60.972), и деревня Верхняя на оз. Верхнее (примерно 40.208; 60.984). Еще важнее то, что карта провинции определенно показывает, что большой участок вологодско-каргопольской границы проходит по течению р. Волошки, включая место впадения в нее р. Долгуши (39.893; 61.098) - это соответствует участку позднейшей каргопольско-вельской границы между точками 39.760; 60.966 и 40.071; 61.163.

В то же время, небольшой участок, перешедший после реформы к Череповецкому уезду Новгородского наместничества, все-таки обнаруживается. Это западная часть Южской волости в юго-западном углу уезда: деревни Гойша (38.338; 59.055), Вытежор, идентифицируемая как современная д. Витержево (38.290; 59.002), Чернево (38.276; 58.997), а также Очинико-

${ }^{15}$ См. об этом: Golubinsky A.A., Alyabina I.O., Shalashova O.V., Khitrov D.A. From survey plans to land cover maps: Data generalization in the cartographic materials of the General Land Survey in Russia (1765-1800) // 26 International Cartographic Conference. Dresden. Germany, August 25 - 30, 2013. Proceedings. Dresden, 2013. 
во, отмеченное Я.Е. Водарским как нелокализуемое, но вполне уверенно соотносимое с деревней Очениково $(38.248 ; 59.023)^{16}$.

Перейдем к северо-восточной границе уезда. Карта Вологодской провинции обозначает этот участок как пограничный с Важским и Тотемским уездами.

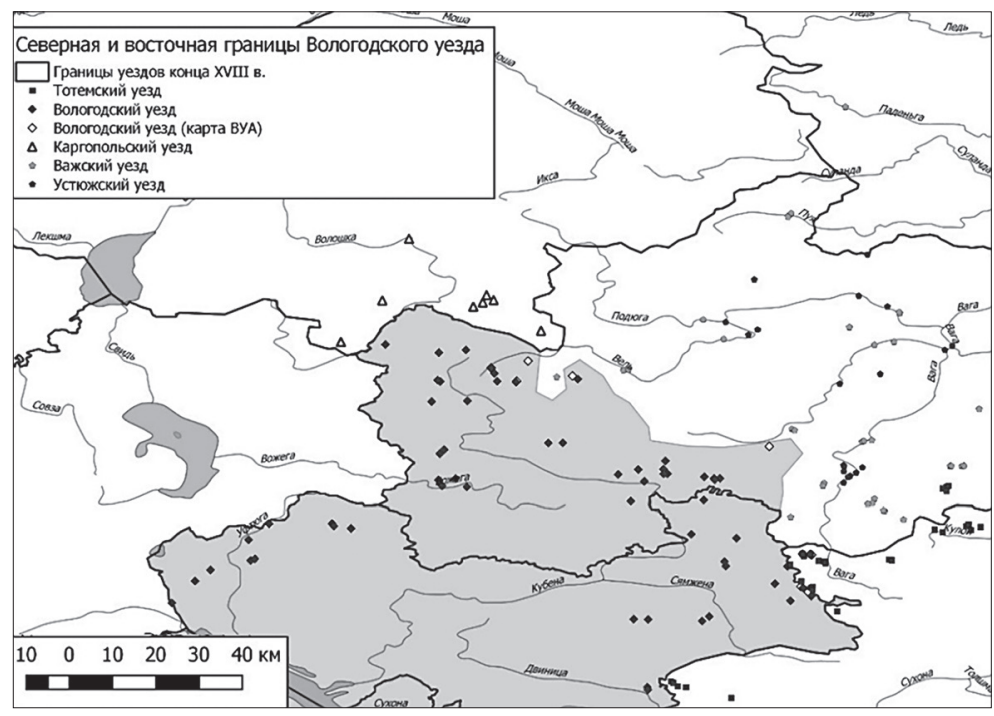

Карта 2. Северная и восточная границы Вологодского уезда

Начнем с вологодско-важского участка. В данном случае у нас нет возможности «опереться» на более поздние карты - исследуемая территория была объединена в составе Вельского уезда, и существовавшая до реформы граница исчезла. Зато этот район, помимо карты Вологодской провинции, отражен на карте северной части Архангелогородской губернии из РГВИА.

Согласно карте БАН, граница проходит по водоразделу систему Кубены и Ваги, с двумя отступлениями: во-первых, к вологодским владениям отнесены верховья рек Велги (Вели) с деревней Кузьминка $(40.309 ; 60.910)$ и Вотченицы (Вотчицы) с селом Ильинским (погост Ильинский недалеко от деревни Даниловская (40.662; 60.864). Во-вторых, показано, что важские владения подходят к верховьям р. Ембы; ниже по ее течению показан ряд вологодских поселений, в частности, деревня Дубровинская (41.245; 60.460). Карта РГВИА позволяет несколько уточнить эти границы: на ней видно,

${ }^{16}$ Водарский Я.Е. Вологодский уезд... С. 365. 
что деревня Толстая в верховьях Вотчицы $(40.577 ; 60.873)$ относится к важским владениям и, таким образом, Важский уезд образует здесь значительный выступ к югу. Кроме того, на этой карте вологодские владения выходят за пределы бассейна Ембы, и за водоразделом, на р. Пенжема, показана принадлежащая к Вологодскому уезду деревня Ереминская (соотносимая, видимо, с Ереминским починком на карте Стрельбицкого и современной деревней Ереминское $(41.445 ; 60.591)$. В районе соединения границ пореформенных Вельского, Тотемского и Кадниковского уездов (41.524; 60.181) или немного севернее этой точки граница снова начинает соответствовать позднейшей — в данном случае, восточной границе Кадниковского уезда.

Участок вологодско-тотемской границы реконструируется значительно более уверенно: во-первых, в нашем распоряжении появляется подробная карта Тотемского уезда ${ }^{17}$, а во-вторых, авторы карты Вологодской провинции явно стремились подробно отразить приграничную топонимику и с вологодской стороны границы. Частично эта граница видна и на карте РГВИА.

Как хорошо видно на карте 2, она по большей части совпадает с позднейшим кадниковско-тотемским рубежом. Существенное отличие касается только области вдоль течения Сухоны: дореформенный рубеж проходил немного выше впадения в Сухону Векшенги, оставляя с. Мотыри (41.336; 59.402), Шуйск с Шуйским ямом (41.040; 59.378) и течение рек Шуи и Шейбухты за Вологдой, а после реформы он сместился выше, так что эти территории отошли к Тотьме.

Реконструкция протяженной южной границы Вологодского уезда вызывает наибольшие сложности (см. Карту 3).

Восточная ее часть отражена на другой части карты Архангелогородской губернии из РГВИА; сложность, однако, состоит в том, что сама эта карта, видимо, довольно приблизительно отражает реальную ситуацию на пограничных с Вологодским уездом территориях, где до екатериниской реформы чересполосно располагались поселения сразу трех уездов, причем приналежавших к разным провинциям - Ярославского, Галицкого и Любимского (Костромской провинции). В общих чертах граница близка к границе Грязовецкого уезда с Любимским, Буйским и Солигалическим уездами Костромского наместничества в пореформенное время. В то же время целый ряд фактов не укладывается в эту простую схему.

Прежде всего, в верховьях р. Монза к территории Галичского уезда отнесены Успенский погост и деревня Шабалкова, которые, видимо, следует идентифицировать как погост Успения на Монзе (41.232; 59.107)

${ }^{17}$ ОР БАН. 533. 


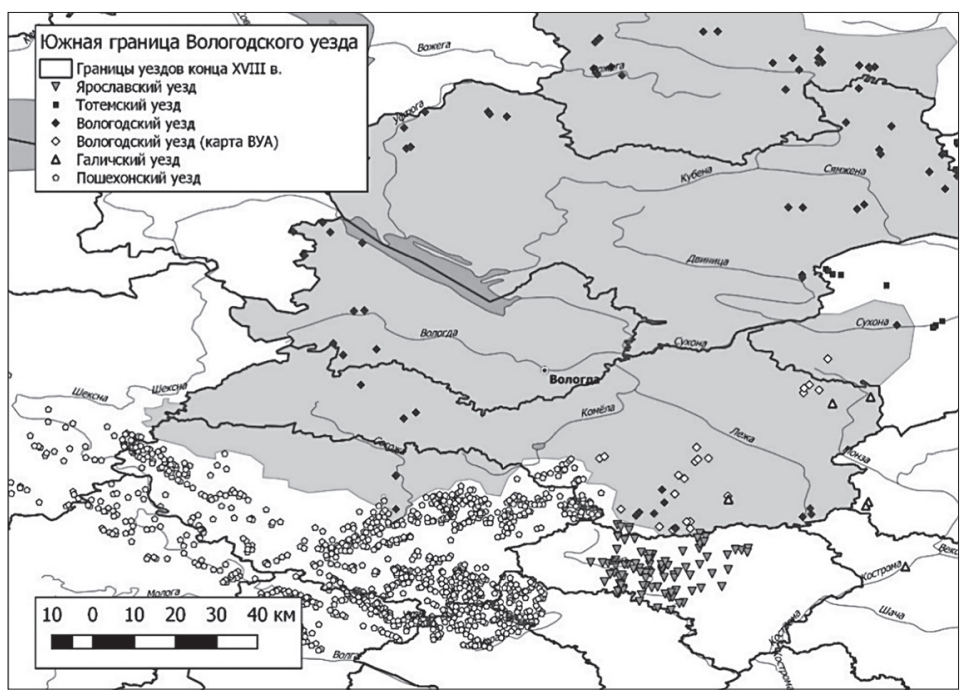

Карта 3. Южная гранииа Вологодского уезда

и Шабалкин починок $(41.074 ; 59.072)$. Если принять это известие, то получится, что при проведении реформы граница вологодских владений сместилась южнее, к с. Демьянову (41.123; 58.884). С другой стороны, в 1618 г. Монзенский Успенский погост числился в Шилегодской волости Вологодского уезда ${ }^{18}$; очевидно, этот вопрос нуждается в дальнейшем исследовании. Имеется и еще одно подобное известие. Западнее, показаны как пограничные деревни Починок (с вологодской стороны) и Заречье (с Галицкой). По карте Стрельбицкого, они могут быть локализованы как $(40.642 ; 58.746)$ и $(40.695 ; 58.642)$. Это также значило бы, что в этом пустынном лесном краю отдельные небольшие галичские поселения могли отойти во время реформы к Вологодскому уезду. Впрочем, не исключена и простая ошибка локализации: подобные названия встречаются довольно часто.

Западнее, имеется небольшой участок границы Вологодского и Ярославского уездов, обозначенный на карте провинции. К сожалению, ее изображение в этой части имеет слишком общий характер, и определить положение границы по ней не удается, других же карт, отражающих дореформенное

${ }^{18}$ Суворов Н. Несколько статистических и топографических сведений о Вологодской епархии от начала XVII столетия до настоящего времени. // Вологодские епархиальные ведомости. 1865. № 21. Прибавления. С. 814. Фото церкви 1734 г. см.: Известия Императорской археологической комиссии, 1916 г. Вып. 59. С. 174. 
деление, в нашем распоряжении нет. Далее следует весьма протяженная граница с Пошехонским уездом, которая также не отражена на картах. В обоих случаях потребовалась достаточно обширная работа, чтобы локализовать все прилегающие к границе поселения: в случае Ярославского уезда Служня стана ${ }^{19}$, в случае Пошехонского - всех поселений уезда ${ }^{20}$. Соотнеся полученные результаты с картой А.Л. Грязнова, мы имеем возможность реконструировать этот участок границы.

Выясняется, что вологодские владения насколько расширились за счет ярославских — села Турыгино (40.191; 58.588), деревень Погорелка (40.206; 58.578), Полянки (40.240; 58.565) и Скалино (40.241; 58.577) после реформы перешли от Ярославского уезда к Грязовецкому. На вологодско-пошехонском рубеже граница, напротив, сильно сместилась к северу - к Пошехонскому уезду отошли среднее течение р. Согожи и весь бассейн р. Большой Юг.

Посмотрим на полученные данные с точки зрения механики осуществления реформы 1775-1783 гг.

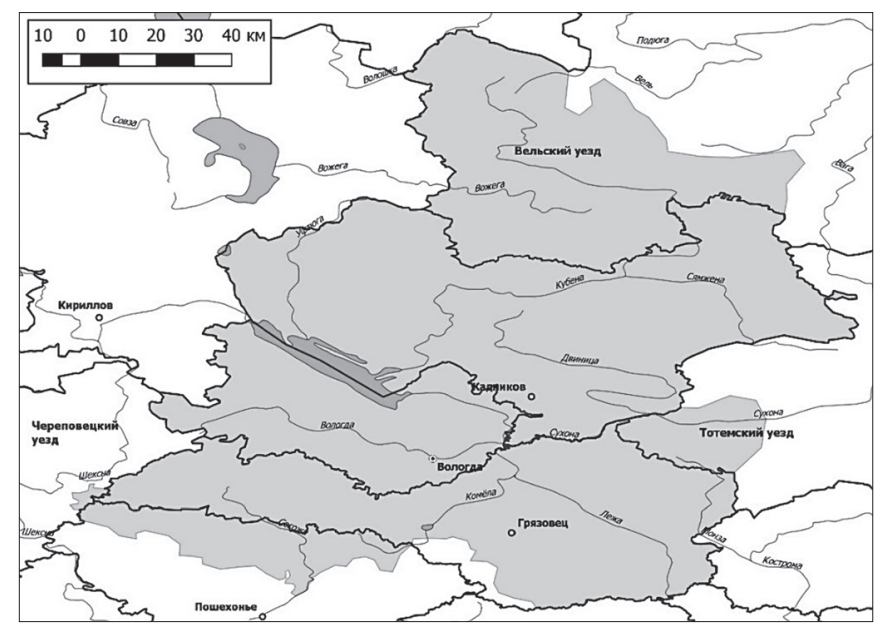

Карта 4. Перераспределение территорий Вологодского уезда в ходе губернской реформы

${ }^{19}$ Перечень поселений по данным 3 ревизии был взят из: РГАДА. Ф. 455. Оп. 1. Ед. хр. 1344. Ведомости о названных селениях Ярославского уезда и о числе душ, находящихся в них.

${ }^{20}$ Использован список поселений по данным 1 ревизии: Ельчанинов И.Н. Помещики и вотчинники Пошехонского уезда по переписной книге комиссара И.У. Мещеринова в 1719 г. // Летопись историко-родословного общества в Москве. 1909. Вып. 4. С. 24 47. Результаты этой реконструкции будут опубликованы отдельно. 
Как мы видели, губернская реформа 1775-1783 гг. привела к глубокому переустройству существовавшей ранее системы административных границ. В то же время нельзя сказать, что старая система деления была полностью ликвидирована, стерта и создана заново, поскольку реформа осуществлялась путем активной передачи определенных участков от одних центров к другим.

Еще до момента открытия Вологодского наместничества часть территорий Вологодского уезда была отчислена от него: при открытии Ярославского ${ }^{21}$ от Вологодской губ. к Пошехонскому уезду отошло 6 тыс. душ. Впрочем, в указе оговаривалось, что, «хотя от Вологодской вышеписанное число к Ярославской ныне по способности присоединится, но токмо для наполнения губернии в числе душ; а действительно уравнять между оными границу тогда, когда Ярославская губерния со всем размежуется». Возмоно также, что небольшой участок отошел к Череповецкому уезду еще при открытии Новгородского наместничества ${ }^{22}$, хотя в указе об этом ничего не говорилось об обмене территориями с Вологодским уездом.

При открытии в 1780 г. Вологодского наместничества «назначение границ сего наместничества с прикосновенными ему» было оставлено «на соглашение генерал-губернаторов и правящих ту должность» ${ }^{23}$, но нового крупного перераспределения территорий не произошло: Вологодский уезд составил основу обширной западной части нового наместничества, и основная часть его территории вошла в состав четырех уездов Вологодской области Вологодского наместничества - Вельского, Кадниковского, Вологодского и Грязовецкого (небольшой участок был также передан Тотемскому). Одновременно в состав Грязовецкого уезда вошли некоторые поселения Ярославского, Любимского, Пошехонского и, вероятно, Галицкого уездов. Тем не менее, как мы видели, основная часть периметра названных четырех пореформенных уездов может быть с большой долей уверенности отождествлена с существовавшими ранее границами старого Вологодского уезда.

Таким образом, можно заключить, что губернская реформа 1775-1783 гг., крупнейшее в истории России дореволюционной эпохи вмешательство государства в систему административного деления страны, не уничтожила традиционную систему территориальных связей на Вологодчине. В силу этого использование карт XVIII в., как до- так и пореформенных, позволяет существенно уточнить расположение границ уездов, существовавших до открытия наместничеств.

\footnotetext{
${ }^{21}$ ПСЗ-І. Т. 20. № 14637.5 августа 1777 г. С. 544.

${ }^{22}$ Там же. № 14500. 24 августа 1776 г. С. 408.

${ }^{23}$ Там же. № 14973. 25 января 1780. С. 911.
} 


\section{Литература}

Атлас Всероссийской империи. Собрание карт И.К. Кирилова. СПб., 1722-1737. Багров Л. История русской картографии. М., 2005.

Buтов M.B. Приемы составления карт поселений XV-XVII вв. по данным писцовых и переписных книг (на примере Шунгского погоста Обонежской пятины) // Сборник Института этнографии АН СССР. М., 1958. Вып. 29. С. 30-37.

Водарский Я.Е. Вологодский уезд в XVII в. (К истории сельских поселений) // Аграрная история Европейского Севера СССР. Вологда, 1970. С. 253-366.

Водарский Я.Е. Население России в конце XVII - начале XVIII века: Численность, сословно-классовый состав, размещение. М., 1977.

Голубинский A.A. Специфика работы представителей семьи Делиль над текстовыми материалами и черновой картографической информацией // Делили в России: сборник статей. СПб., 2019. С. 117-120.

Гольденберг Л.А. Первый академический атлас России и картографические работы Географического департамента Академии наук// Очерки истории географической науки в СССР. М., 1976.

Грязнов А.Л. Карта «Вологодский уезд в XVII в.» // Мой родной Вологодский район. Вологда, 2009. С. 96-97.

Грязнов А.Л., Черкасова М.С. О формировании межуездных границ на Русском Севере в XV-XVI вв.: Белоозеро-Вологда-Устюг// Северная Русь и проблемы формирования Древнерусского государства: Сборник материалов международной научной конференции. Вологда-Кириллов-Белозерск 6-8 июня 2012 г. Вологда, 2012. С. 178-192.

Ельчанинов И.Н. Помещики и вотчинники Пошехонского уезда по переписной книге комиссара И.У. Мещеринова в 1719 г. // Летопись историко-родословного общества в Москве. 1909. Вып. 4. С. 24-47.

Кабузан В.М. Обзор историко-географических источников по административнотерриториальному делению России в 1720-1770 гг.// Историческая география России XVIII в. М., 1981. С. 45-56.

Постников A.B. Новые данные о российских картографических материалах XVIII начала XIX вв. во Франции // Вопросы истории естествознания и техники. 2005. № 3 .

Постников А.B. Развитие крупномасштабной картографии в России. М., 1989.

Суворов Н. Несколько статистических и топографических сведений о Вологодской епархии от начала XVII столетия до настоящего времени. // Вологодские епархиальные ведомости. 1865. № 21. Прибавления. С. 814.

Фель С.Е. Картография России XVIII в. М., 1960.

Черкасова М.С. Северная Русь: История сурового края XIII-XVII вв. М., 2017.

Golubinsky A.A., Alyabina I.O., Shalashova O.V., Khitrov D.A. From survey plans to land cover maps: Data generalization in the cartographic materials of the General Land Survey in Russia (1765-1800) // 26 International Cartographic Conference. Dresden. Germany, August 25-30, 2013. Proceedings. Dresden, 2013. 